بررسى تغييرات جريان سطحى و زيرزمينى در حوضه آبريز سمنان با استفاده از مدل SWAT

$$
\text { شيما نصيرى' و ؟**، نغار فرّهى' و على نقى ضيائى ' }
$$

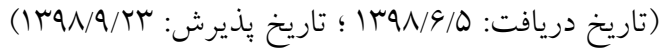

جكيده

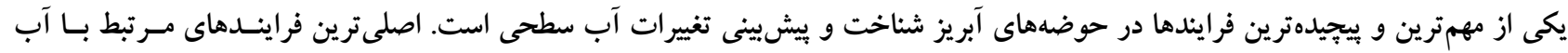

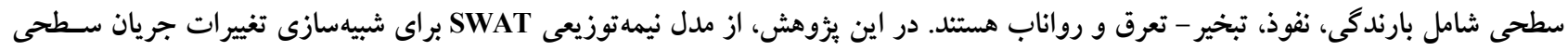

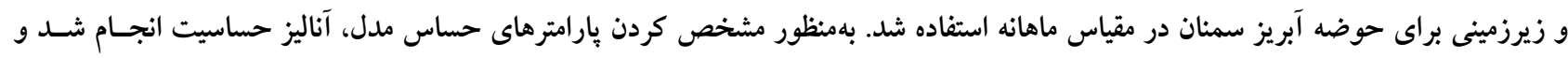

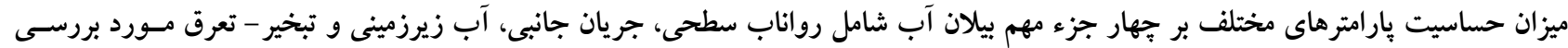

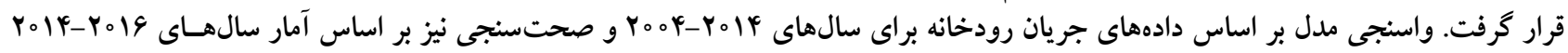

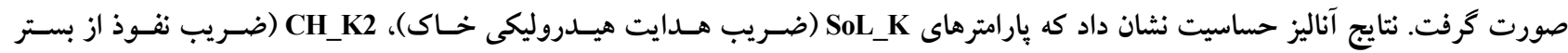

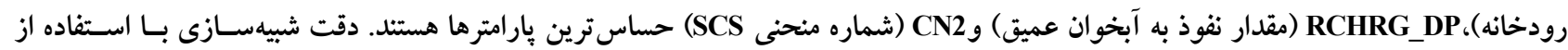

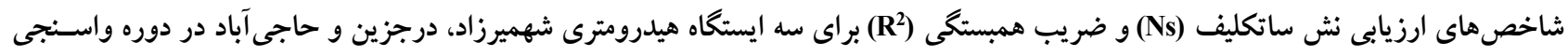

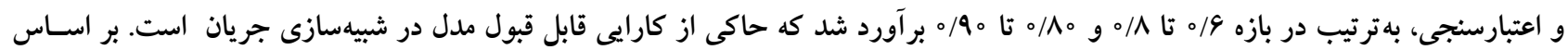

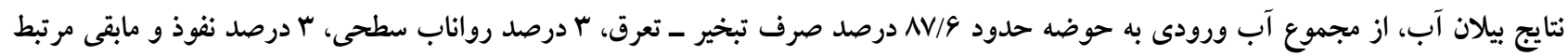

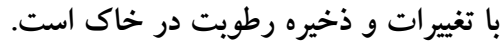

$$
\text { وازههاى كليدى: رواناب، نفوذ، الخوريتم SUFI2، آب زيرزمينى، بيلان آب }
$$


رفتارهاى هيدرولوزيكى و نحوه تغييرات و اثرات آن و هــف

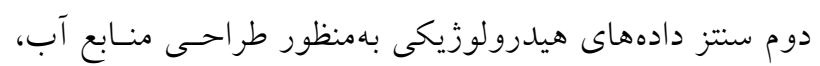

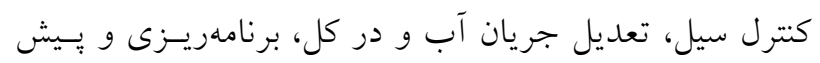

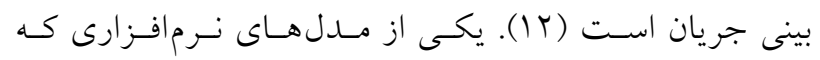

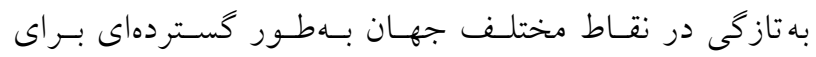

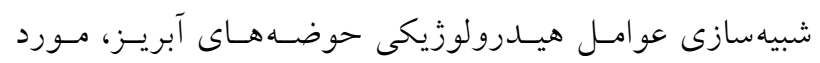

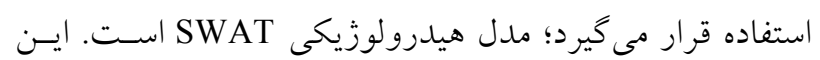

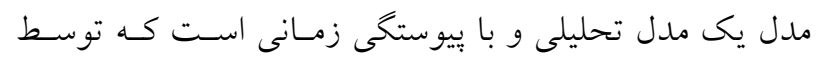
سرويس تحقيقـات كشـاورزى امريكـا تهيـه شـــه اسـت (Y).

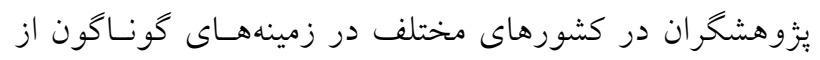

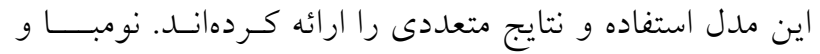

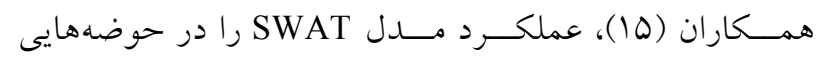
بـا دادهاى كم در تانزانيا بررسـى كردند. نتايج آنها نشــان

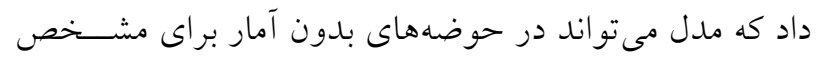

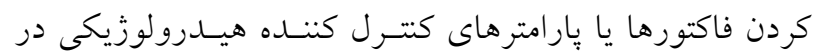

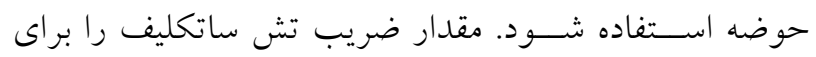

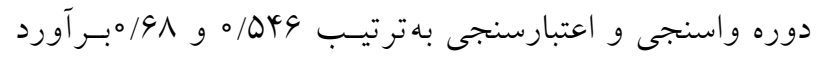

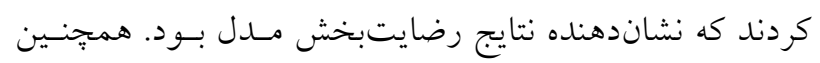

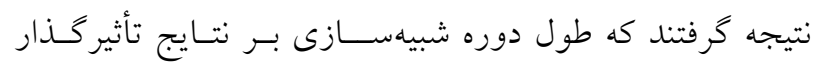

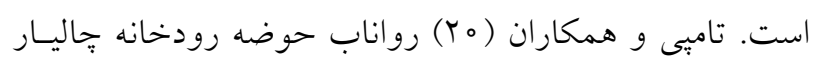

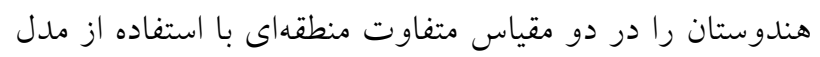

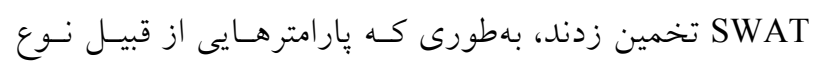

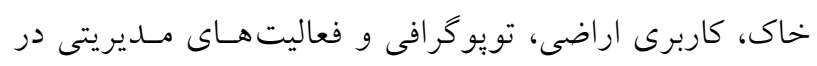

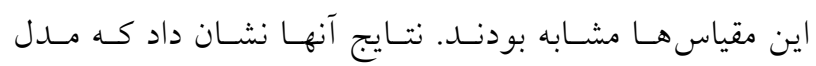

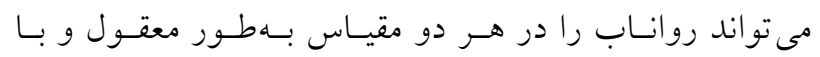

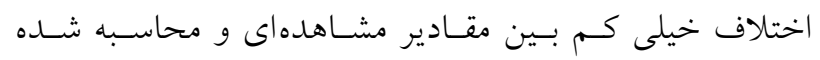

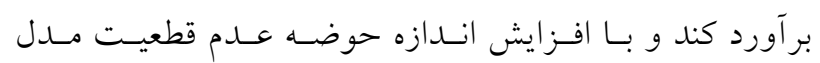

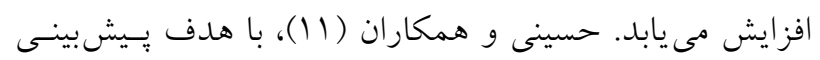

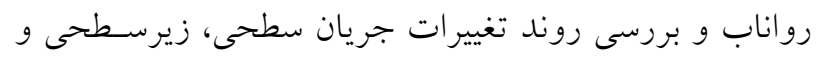

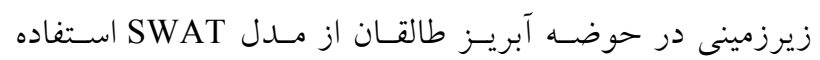
كردند، كه اين مدل در دورههاى زمانى سالانه و ماهانسه نتسايج

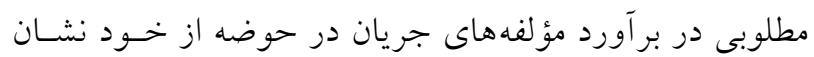

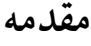

فرايندهاى مـرتبط بــا خرخـهـ آب در طبيعـت داراى ارتبـاطى

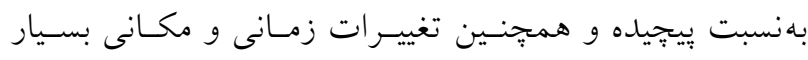

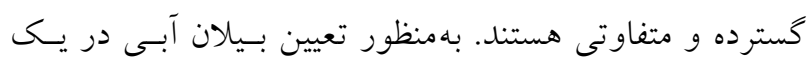

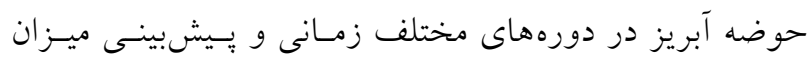

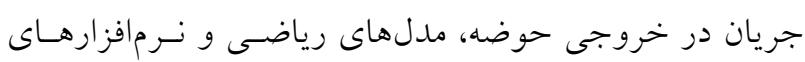

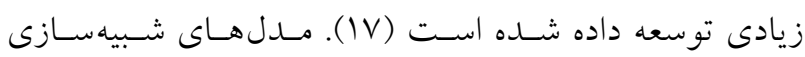

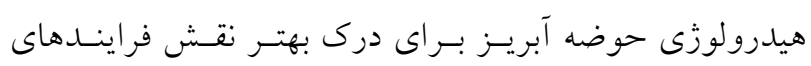

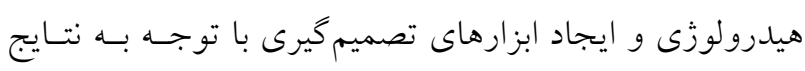

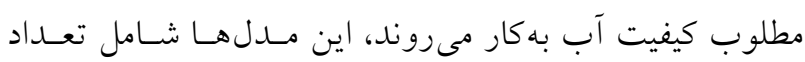

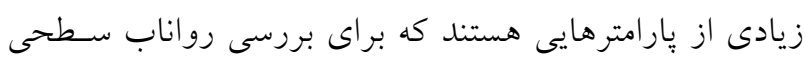

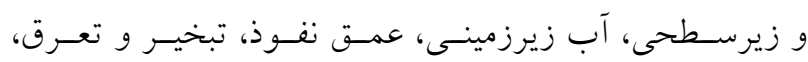

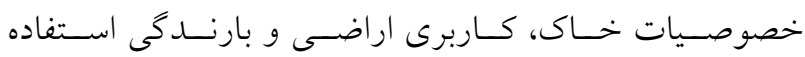

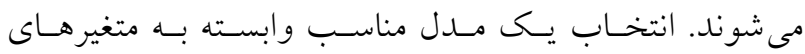

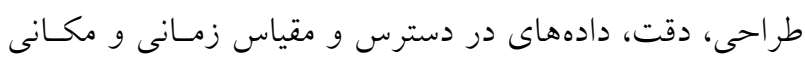

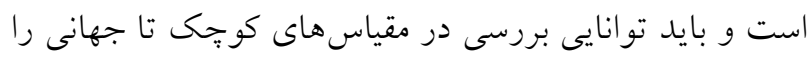
داشته باشد (IY). شبيهسازى بارش- روانـاب يكى از مـوارد كليدى در علوم هيدرولوزى و مديريت محيط زيست بهشـمار

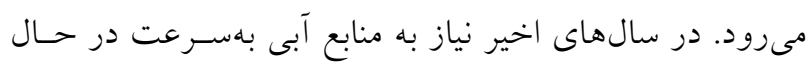

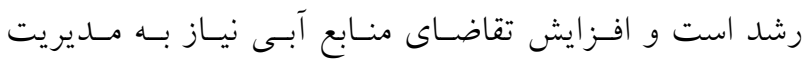

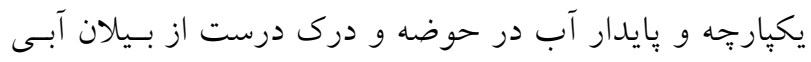

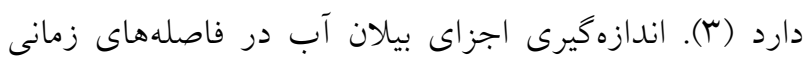

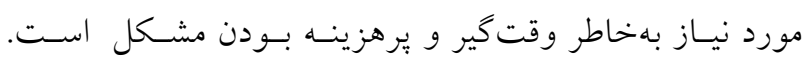

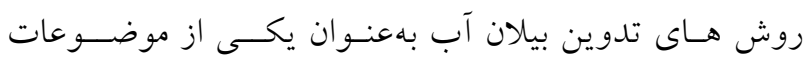

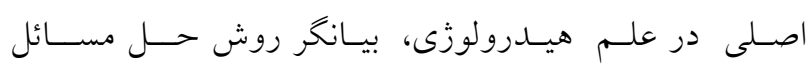

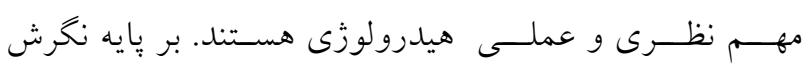

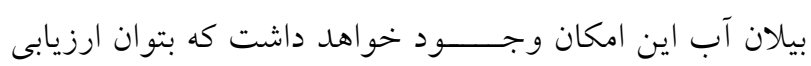

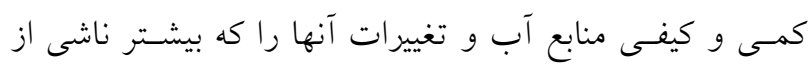
فعاليتهاى بشر است انجام داد. لذا شبيهسازى مؤلفههاى

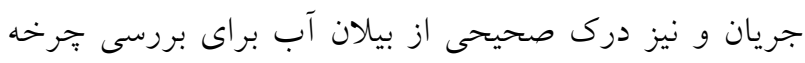

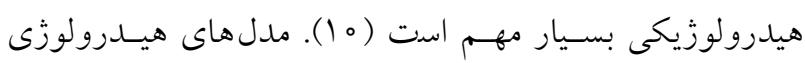

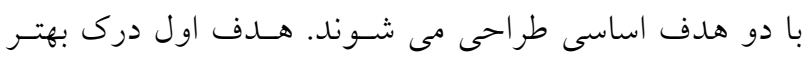




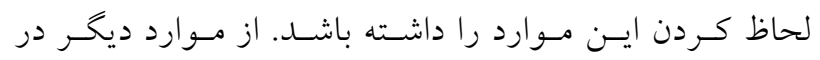

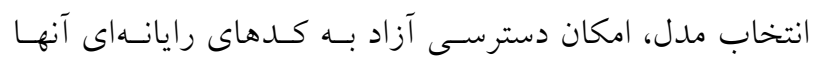

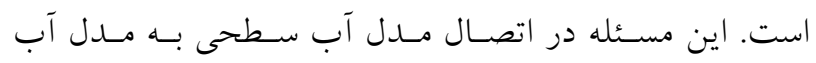

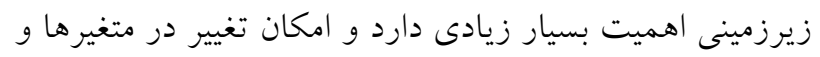

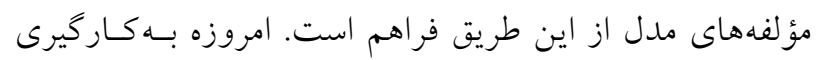
مدل SWAT بـهـمــراه برنامـ SWAT-CUP در شـبيهسـازى

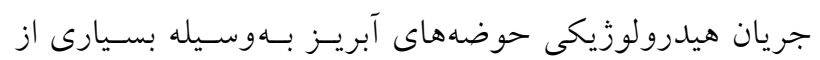

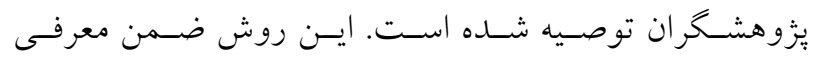

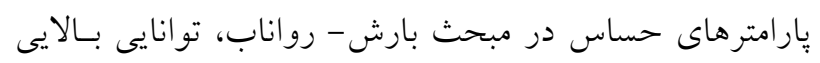

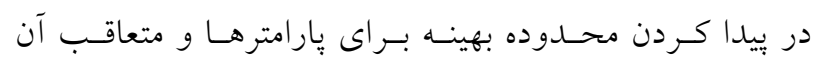

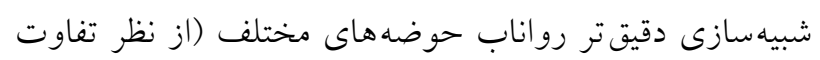

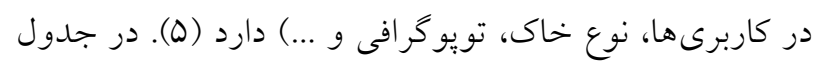

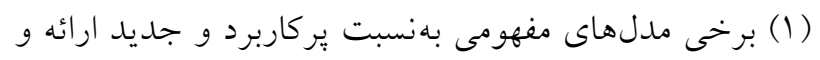

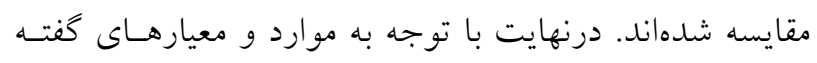

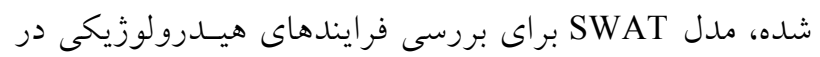

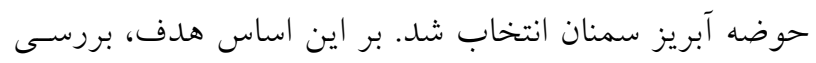

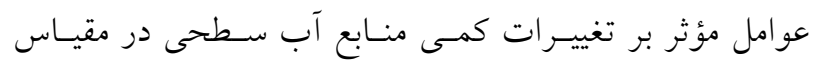

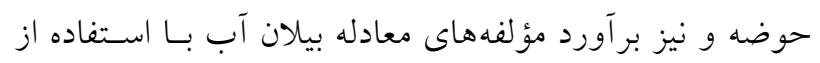

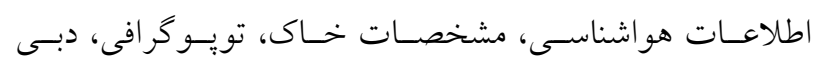

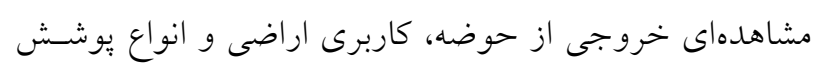

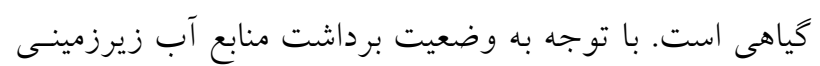

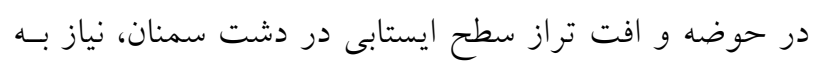

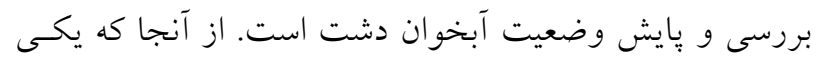

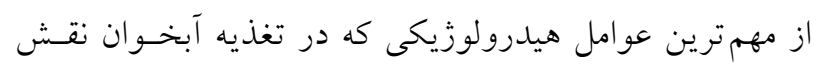

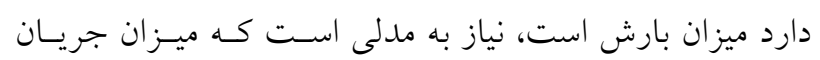

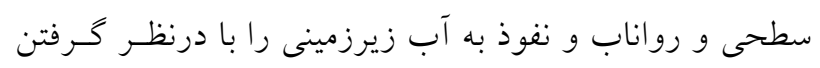

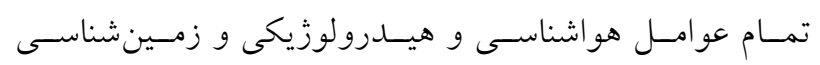

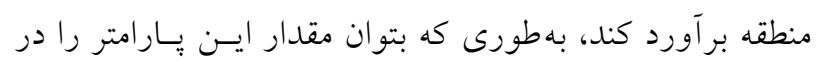

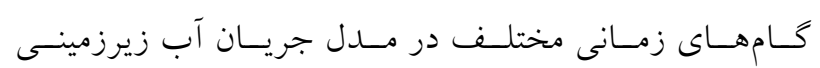

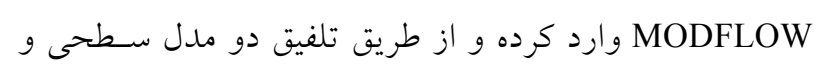

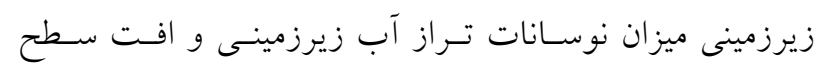
ايستابى را تخمين زد.
داد. كلشن و همكاران (^) كارايى ايسن مـــل در شـبيهسـازى

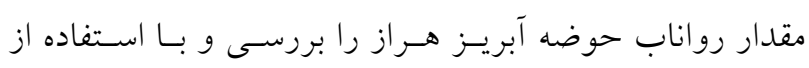

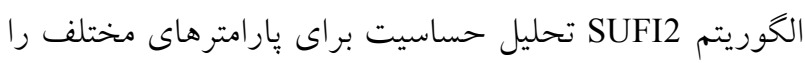

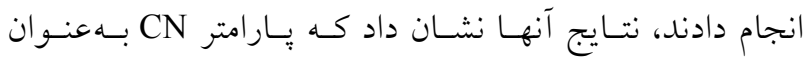

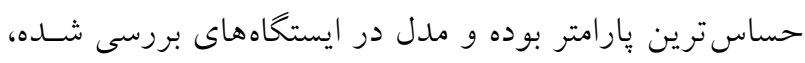

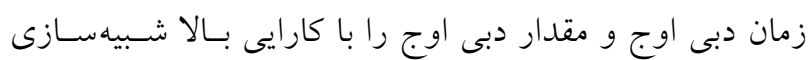
مى كند.

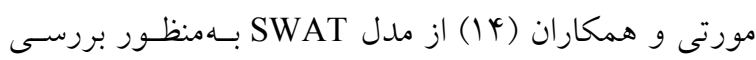

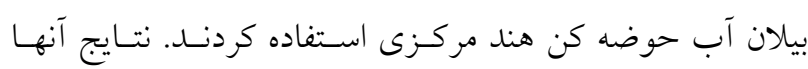

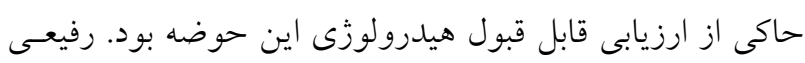

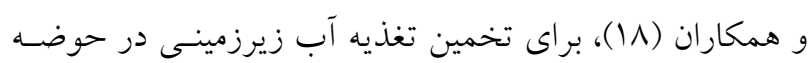

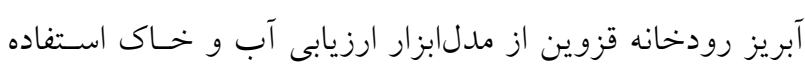

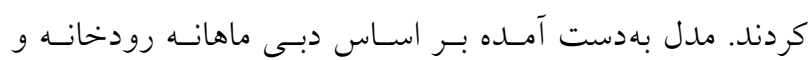

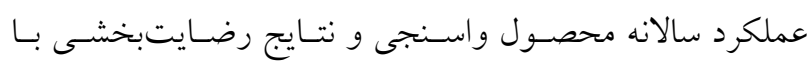

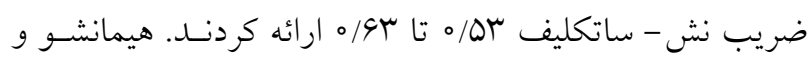

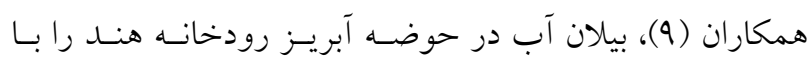

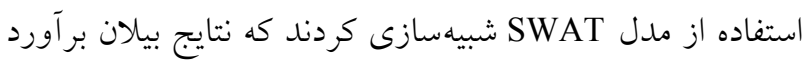

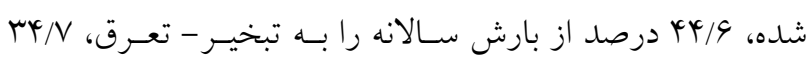

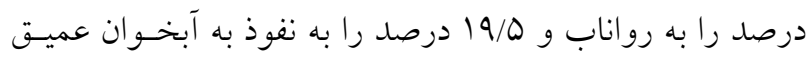

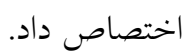
هدف اصلى، شبيهسازى فرايندهاى هيـدرولوزى محسـدوده

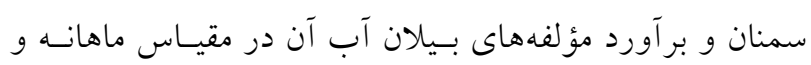

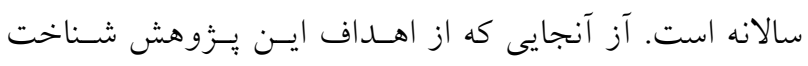

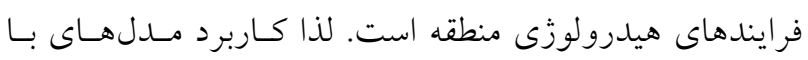

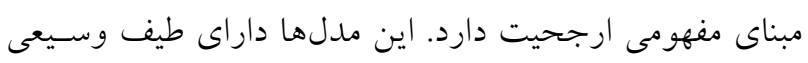

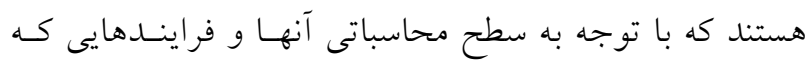
قابليت شبيهسازى آنها را دارند انتخاب و مـورد اسـتفاده قـرار

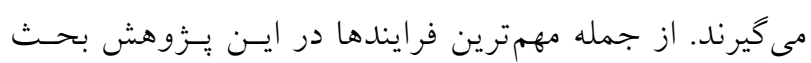

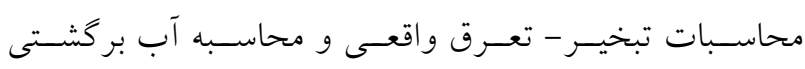

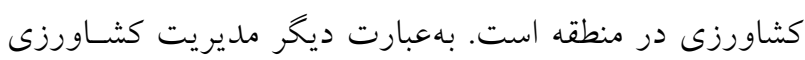

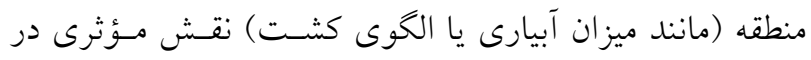

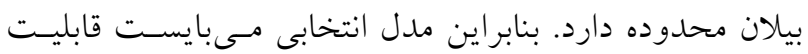


جدول ا. مقايسه برخى مدلهاى مفهومى و ير كاربرد هيدرولوزى

\begin{tabular}{|c|c|c|c|c|}
\hline دسترسى به كد رايانهاى & امكان لحاظ كردن مديريت كشاورزى & نياز داده ورودىى & مقياس مكانى شبيه سازى & 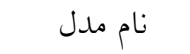 \\
\hline محدود & دارد & زياد & ت ت توزيعى & $\mathrm{mHM}$ \\
\hline محدود & 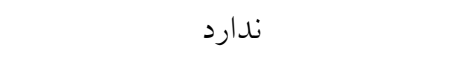 & 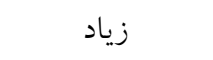 & ت توزيعى & VIC \\
\hline 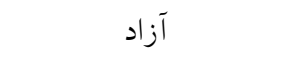 & 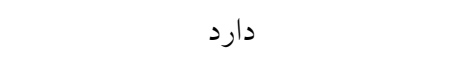 & زياد/ متوسط & نيمه توزيعى & SWAT \\
\hline 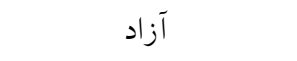 & 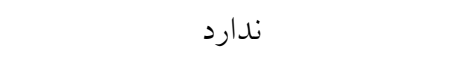 & متوسط & نيمهتوزيعى / غيرتوزيعى & FLEX \\
\hline آزاد & 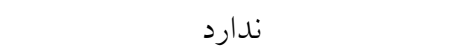 & كم & غيرتوزيعى & HBV, Hymod \\
\hline
\end{tabular}

رودخانه نيز در مجموع Y/Y ميليون مترمكعـب بـوده كـه تمـام آب برداشت شده به مصرف كشاورزى مىرسـد. (شـكل Y). بـهمنظـور تعيين نوسانات سطح آب زيرزمينى، آبنمـود معسرف (هيـدروكراف واحد) با توجه به موقعيت جاهاهاى مشاهدهاى براى سالهـاى آبسى

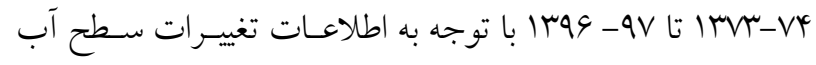
در زّاههاى مشاهدهاى دريافت شده از آب منطقهاى اسـتان سـمنان

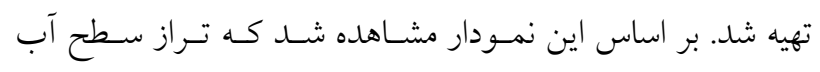
زيرزمينى دشت در طى سب سال آبى اخير حدود 19/0 متر و بهطور متوسط سالانه بالغ بر V/ متر افت داشته است.

\section{معرفى مدل SWAT}

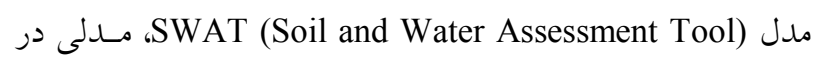
مقياس حوضه آبريز است كه براى يــيشبينى تـأثير روشهـاى

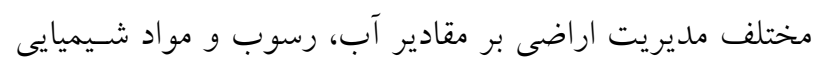

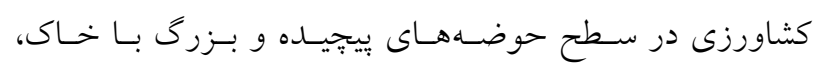
كاربرى اراضى و شرايط مختلف مديريتى در درازمدت طراحسى شده است. اين مدل به منظور شبيهسازى جرخحه هيدرولوزيك از

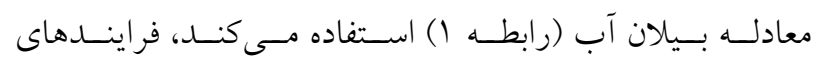
هيدرولوزيكى كه شبيهسازى مسىشـوند شـامل تبخيـر - تعـرق، رواناب سطحى، ذوب برف، نفوذ سطحى، نفوذ عمقى، جريـان آب زيرزمينى و جريانهاى زيرسطحى هستند: $\mathrm{SW}_{\mathrm{t}}=\mathrm{SW}_{\mathrm{o}}+\sum_{\mathrm{i}=1}^{\mathrm{t}}\left(\mathrm{R}_{\text {day }}-\mathrm{Q}_{\text {surf }}-\mathrm{E}_{\mathrm{a}}-\mathrm{W}_{\text {sep }}-\mathrm{Q}_{\mathrm{gw}}\right)$

در اين رابطه، SW مقدار نهايى آب در خاى (ميلىمتـر)، SW0

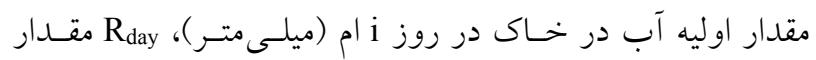

\section{مواد و روش ها موقعيت منطقه مورد يُوهش} محدوده مطالعاتى سمنان يكى از محسدودههـاى مطالعـاتى حوضـهـ

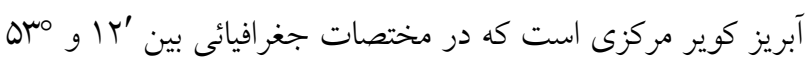

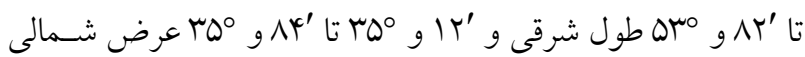

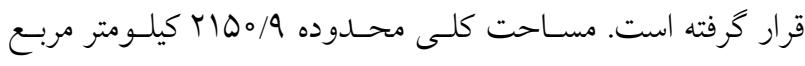

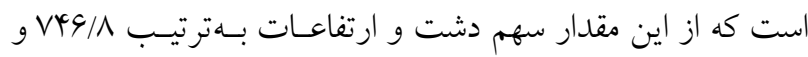

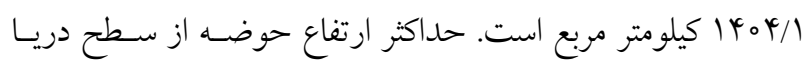

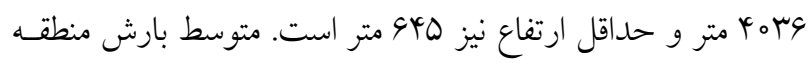

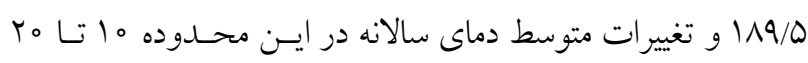
درجه سانتى گراد است. اين محدوده داراى سه ايستخاه هيـدرومترى درجزين، حاجى آباد سمنان و شهميرزاد است. مهمتـرين رودخانسه و زهكش اصلى اين محدوده، رودخانه شورآب به طول تقريبى

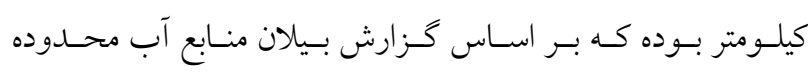
مطالعاتى سمنان، متوسط سالانه دبى خروجى از اين محدوده معادل

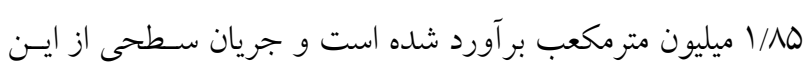
محدوده نيز به كوير سمنان وارد مسىشـود. مشخصـات و موقعيـت ايستخاههاى فعال واقع در محدوده مطالعاتى سمنان و اطراف آن كـه ئه در اين يزوهش مورد استفاده قرار گرفتهاند در جــدول (Y) و شـكل

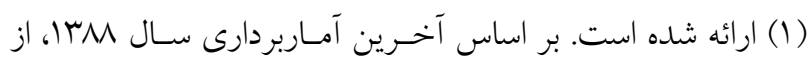

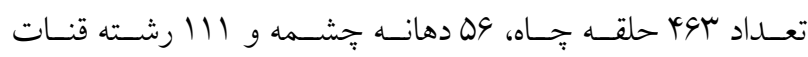

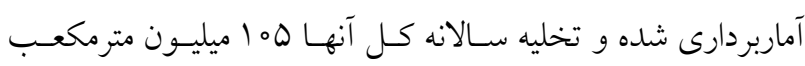
است كه مصرف كشاورزى بيشترين سهم را بهخود اختصـاص داده

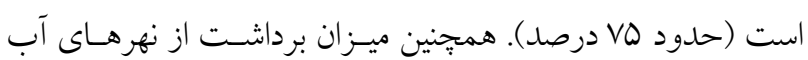



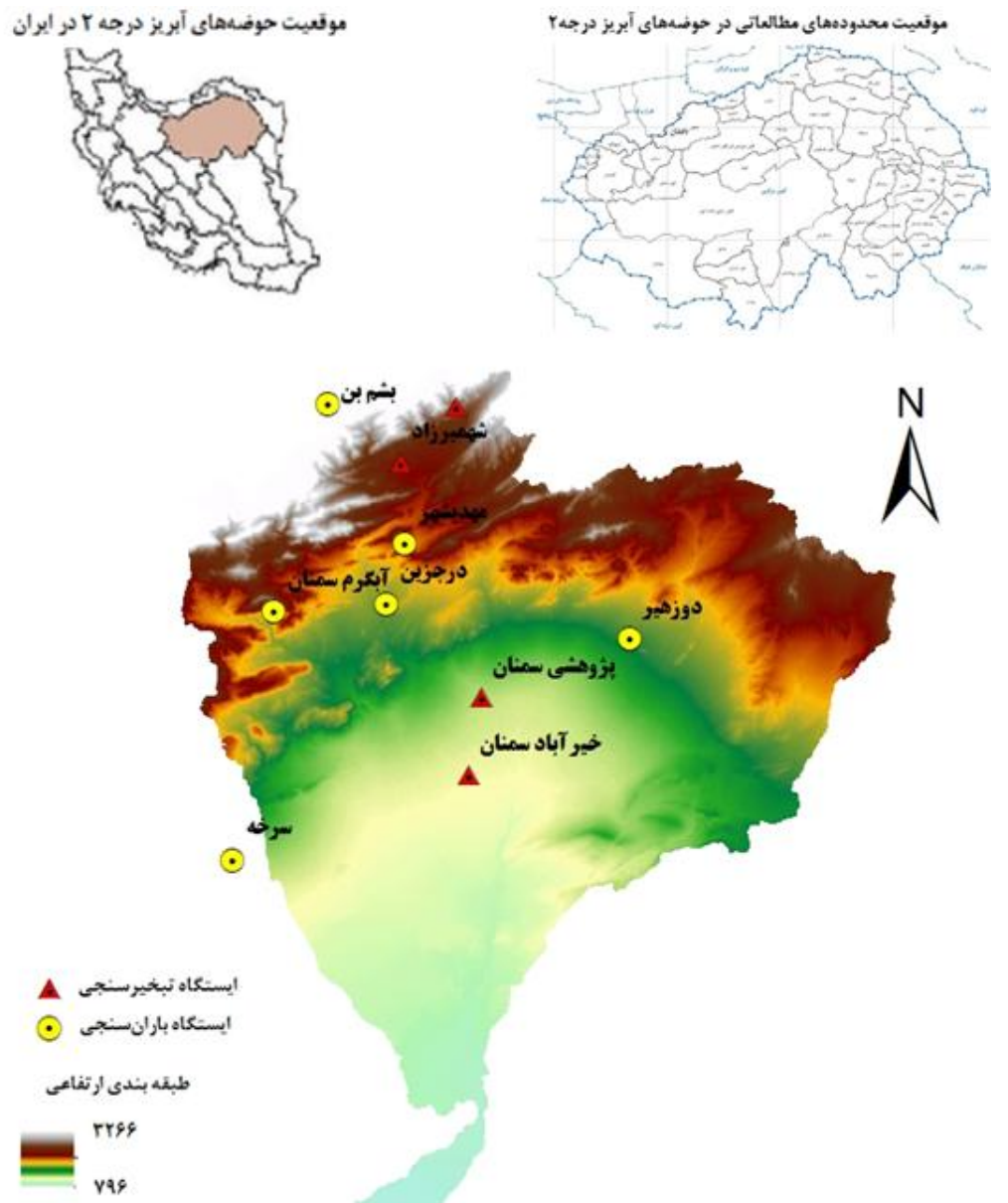

شكل 1. موقعيت حوضه آبريز سمنان و ايستخاههاى واقع در محدوده مطالعاتى و اطراف آن

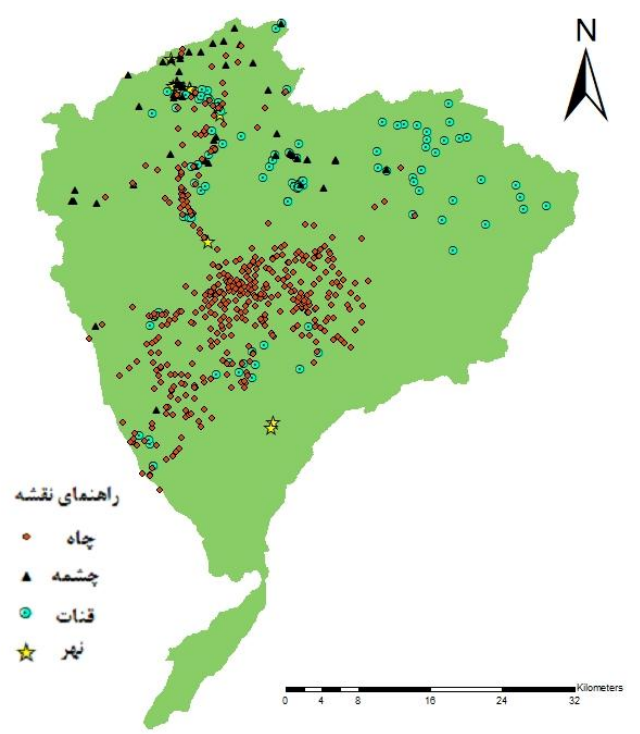

شكل r. منابع آب زيرزمينى و سطحى در محدوده مطالعاتى 
جدول r. مشخصات ايستخاههاى هو اشناسى و هيدرومترى در محدوده مطالعاتى سمنان

\begin{tabular}{|c|c|c|c|c|c|}
\hline سال تأسيس & نوع ايستخاه & ارتفاع ايستگاه (متر) & عرض شمالى & طول شرقى & ن ام ايستخاه \\
\hline$|r 4|$ & بارانسنج معمولى & 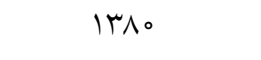 & rq49019 & VIIFVI & درجزين \\
\hline$|r 4|$ & بارانسنج معمولى & $I V \circ \circ$ & 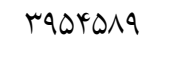 & VITVV。 & مهلديشهر \\
\hline ITVT & بارانسنج معمولى & 1900 & TQYATQ。 & V०YIO० & آبخرم سمنان \\
\hline$|r G|$ & بارانسنج معمولى & 1100 & rarVrGo & $999 \wedge 9 \wedge$ & سرخه \\
\hline 1490 & بارانسنج معمولى & YIN。 & r99091。 & $\vee \circ \Delta \Delta \circ \wedge$ & بشم بن \\
\hline$|r G|$ & بارانسنج معمولى & IVoo & TQYVADT & VTYTIT & دوز دير \\
\hline IrGV & بارانسنج معمولى & סחזץ & rqDYVOT & $9 \wedge \mu \mid \wedge 9$ & كَنداب بشم \\
\hline Irke & تبخيرسنجى & 1090 & rarog० & VIqMNI & خير آباد سمنان \\
\hline$|r v|$ & تبخيرسنجى & rro。 & rasqसाt & V19419 & ده صوفيان \\
\hline 11490 & تبخيرسنجى & 1140 & TqKYITO & $V T \cdot 1 \circ D$ & يزوهشى سمنان \\
\hline 1490 & تبخيرسنجى & $r \circ Q_{0}$ & rasirlo & VII $9 v 9$ & شهميرزاد \\
\hline IrAD & تبخير سنجى & 1900 & $p q 4 \circ 9 \circ q$ & GAGYVI & افتر \\
\hline$|r 4|$ & هيدرومترى & $1 Y \Lambda_{0}$ & rqprva。 & VIf. 19 & درجزين \\
\hline IrAV & هيدرومترى & $r \circ \Delta r$ & rasılry. & $V \circ Q \mu \wedge D$ & شهميرزاد \\
\hline$|r|$ & هيدرومترى & $\Lambda V^{\circ}$ & TATOAVD & VTIAVQ & حإِى آباد سمنان \\
\hline
\end{tabular}

$$
\begin{aligned}
& \mathrm{R}^{2}=\frac{\left[\sum_{\mathrm{i}=1}^{\mathrm{n}}\left(\mathrm{O}_{\mathrm{i}}-\overline{\mathrm{O}}\right)\left(\mathrm{P}_{\mathrm{i}}-\overline{\mathrm{P}}\right)\right]}{\sum_{\mathrm{i}=1}^{\mathrm{n}}\left[\left(\mathrm{O}_{\mathrm{i}}-\overline{\mathrm{O}}\right) \sum_{\mathrm{i}=1}^{\mathrm{n}}\left(\mathrm{P}_{\mathrm{i}}-\overline{\mathrm{P}}^{2}\right]\right.} \\
& \mathrm{Ns}=1-\frac{\sum_{\mathrm{i}=1}^{\mathrm{n}}\left(\mathrm{P}_{\mathrm{i}}-\mathrm{O}_{\mathrm{i}}\right)^{2}}{\left(\mathrm{O}_{\mathrm{i}}-\overline{\mathrm{O}}\right)^{2}} \\
& \text { Rfactor }=\frac{\frac{1}{\mathrm{n}} \sum_{\mathrm{i}=1}^{\mathrm{t}}\left(\gamma_{\mathrm{ti}, 97.5 \%}^{\mu}-\gamma_{\mathrm{ti}, 2.5 \%}^{\mu}\right.}{\sigma_{\mathrm{obs}}}
\end{aligned}
$$

در اين روابط R2 ضريب همبستكى، Ns ضريب نش سساتكليف،

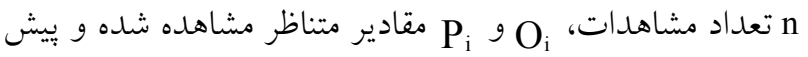
بينى شده هستند،

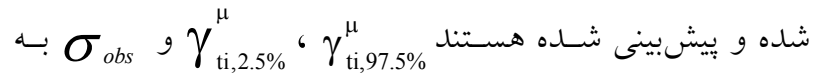

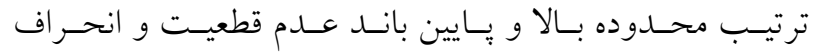

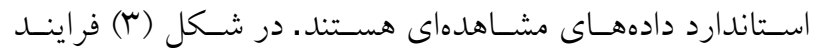
مدلسازى با مدل SWAT نشان داده شده است.

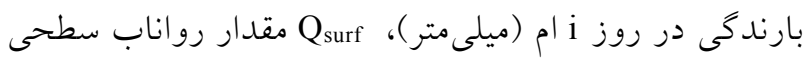

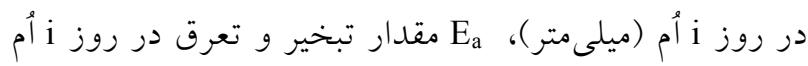

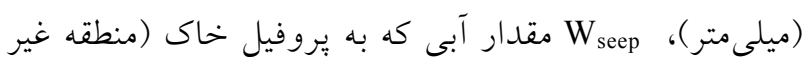

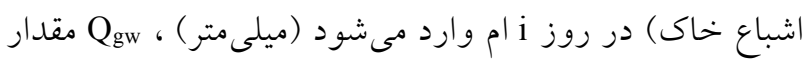

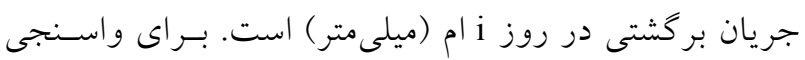

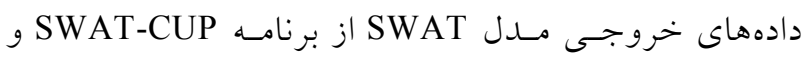

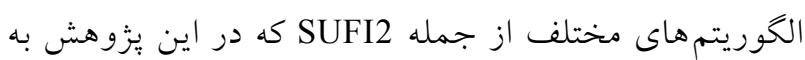
كار رفت، استفاده مىشود. اين الحوريتم توانايى انجام تحليل

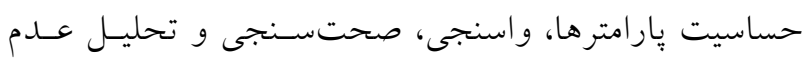

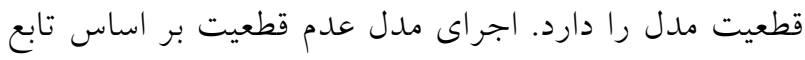

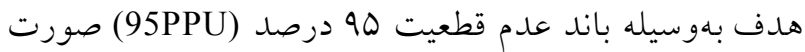
مى گيرد (ا و r). در اين يزوهش، بهمنظور ارزيسابى اجـراى

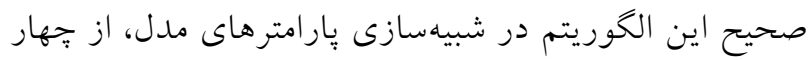

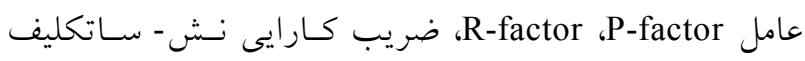
(Ns) 


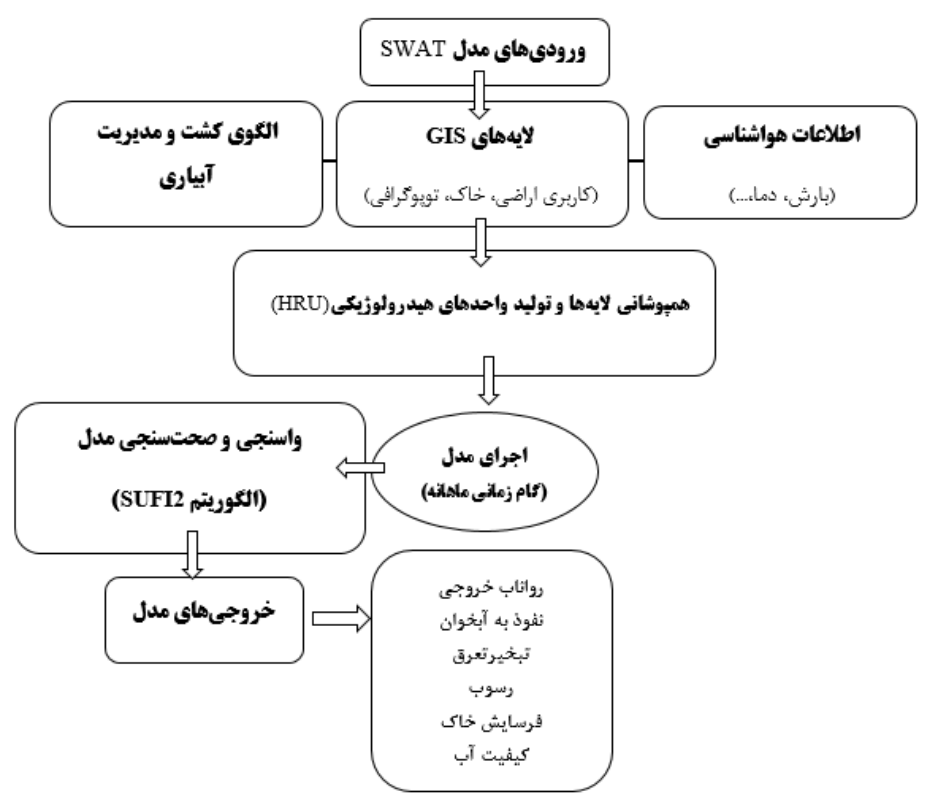

شكل r. فرايند مدلسازى با مدل SWAT

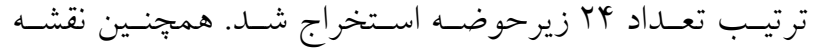
واحدهاى خاى منطقه و لايه كاربرى اراضى محدوده مطالعـاتى كه توسط اداره منابع طبيعى استان سمنان تهيه شده، با استفاده از دادهاى سـنجش از دور و تصـاوير سـرى مـاهوارهاى لندسـت

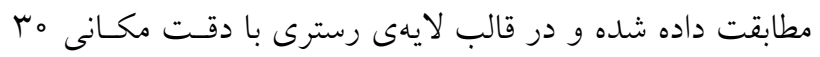
متر به مدل وارد شد. هر يك از يوششهاى كياهى تعريف شده در مدل SWAT بهصسورت يـك كُــ جههار حرفى در جـدول اطلاعاتى لايه وارد مىشوند (19) كه در جدول (r) مشخصـات كاربرى اراضى و كد انتخاب شده بــراى مـــل نشـان داده شـــه

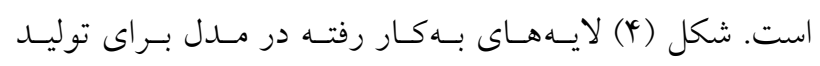
واحدهاى هيدرولوزيك را نشان مىدهد. براى اعمال مديريت كياهى در مدل، بررسى الخوى كشت و شناسـايى محصــولات غالـب، تــاريخ كشـت محصـولات، دور آبيارى و عمق آبيارى از اطلاعات اصلى اسـت كـه ورود آن بـهـ مدل موجب افزايش دقت مدل در تخمين مؤلفههاى بـيلان آب به خصوص تبخير - تعرق واقعى و تغذيسه آب زيرزمينى مسى شود. محاسبه عمق آبيارى با استفاده از برداشتهاى انجام شــه لهري از منابع آب سطحى و زيرزمينى با توجه به الكوى كشت غالـب

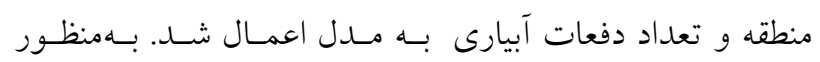

آمادهسازى و تنظيم دادههاى ورودى مدل بهمنظور ارزيابى دقيقتر و شناسايى هر جهه بيشـتر حوضـهـ آبريسز

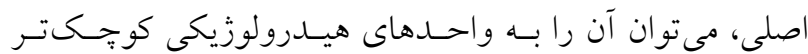
(زيرحوضه) تقسيمبندى كرده و هر يك را بهطسور مجـزا مـورد بررسى قرار داد. مطابق با شبكه آبراهههاى هر حوضـه، يكسى از

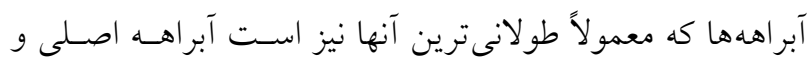
بقيه آبراهلهاى فرعى هستند. همجينين زيرحوضهها بـهـ تعـدادى

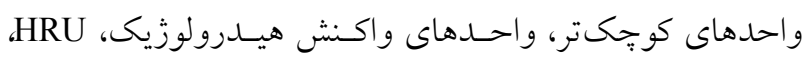
تقسيم مىشـوند. ايسن واحــــا (Hydrologic Response Unit) تا حد امكان مشابه هستند و داراى تركيبات يكسـانى از خـاك،

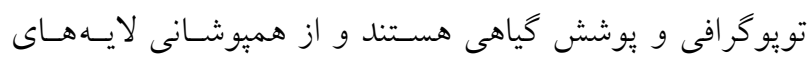

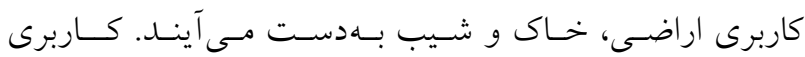

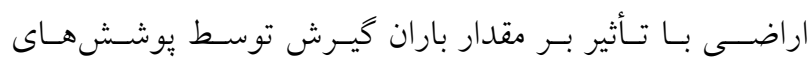
گياهى (Interception) تبخيـر - تعـرق و هــايت هيـدروليكى

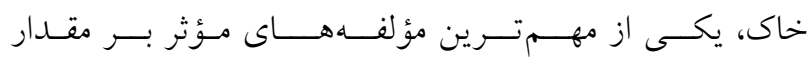
روانـاب سـطحى، دبى رودخانهها و حمـل و انتقـال رســوبات رودخانهاى است (سا و 19). در ايسن مطالعـهـ بـر اسـاس مــدل

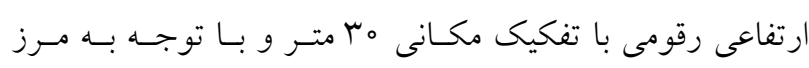

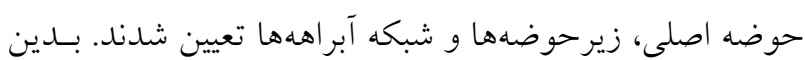


نشريه علوم آب و خاك / سال بيست و جهارم / شماره دوم / تابستان 9هـ1
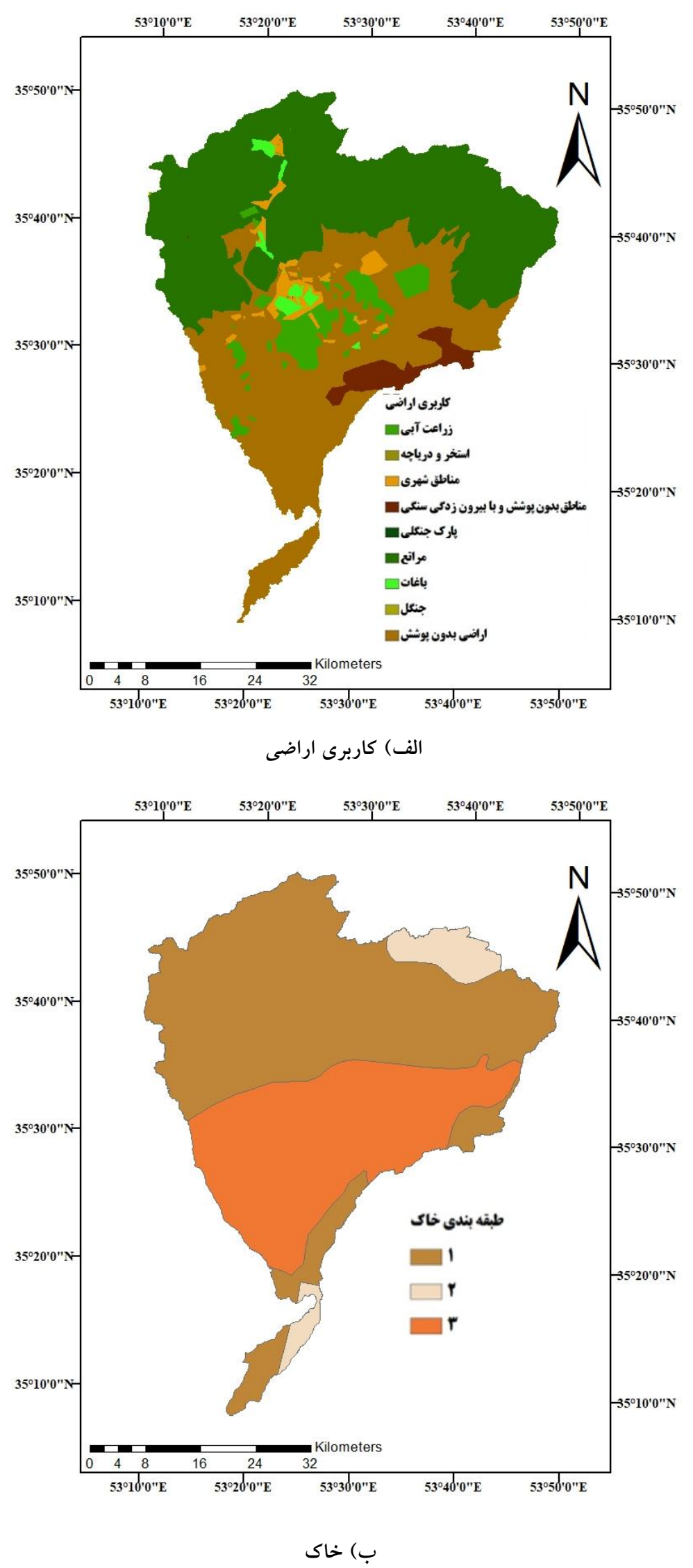


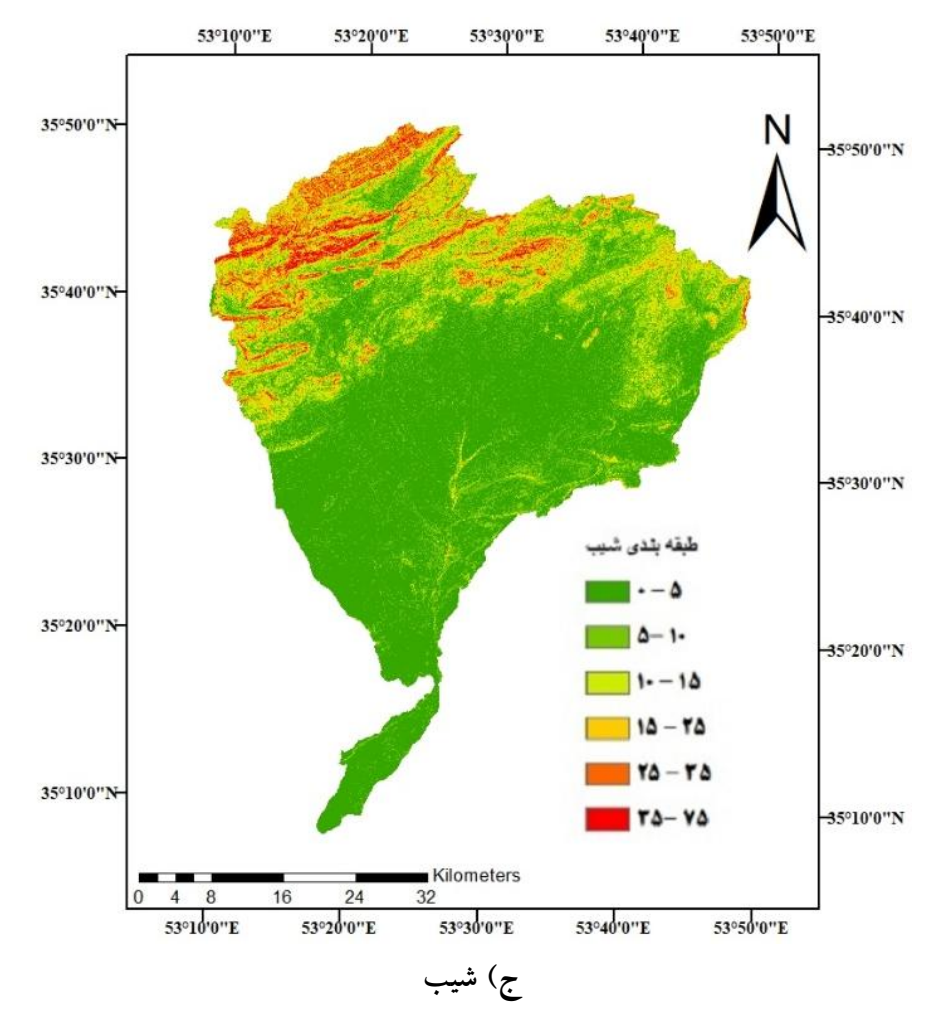

شكل ₹ألايههاى ورودى به مدل: الف)كاربرى اراضى، ب) خاك و ج) شيب

جدول r. طبقهبندى كاربرى اراضى محدوده مطالعاتى

\begin{tabular}{|c|c|}
\hline كد & كلاس هاى كاربرى اراضى \\
\hline WWHT & زراعت آبى (كندم زمستانه) \\
\hline WATR & حوضجه و استخر \\
\hline URNB & مناطق مسكونى و شهرى \\
\hline TUBG & مناطق بدون يوشش و با برونزدكى سنخى \\
\hline PINE & 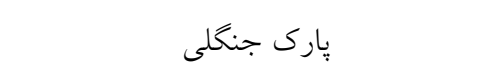 \\
\hline PAST & 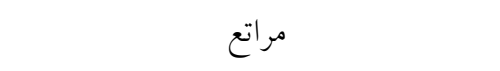 \\
\hline ORCD & 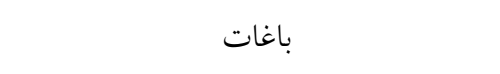 \\
\hline FRST & 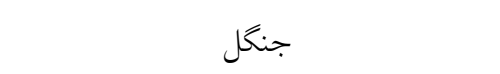 \\
\hline BARR & مناطق بدون يوشش \\
\hline
\end{tabular}

تا و Y T | انجام شد. بهمنظور واسنجى مدل بـههمـراه تحليـل عـدم

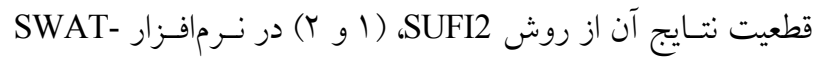

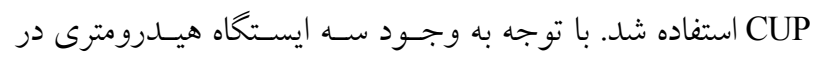

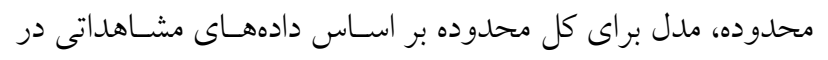

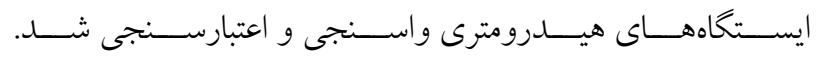

شبيهسازى حوضه، يك دوره ها ساله انتخاب شد. اجراى مــل بـر

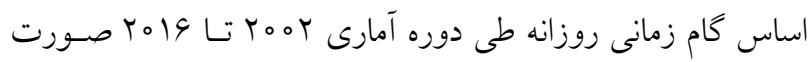

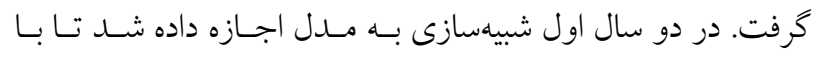
شرايط محيطى متعادل (warm up) شود. واسنجى بــر اسـاس سـال

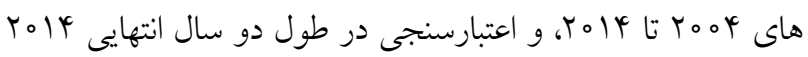



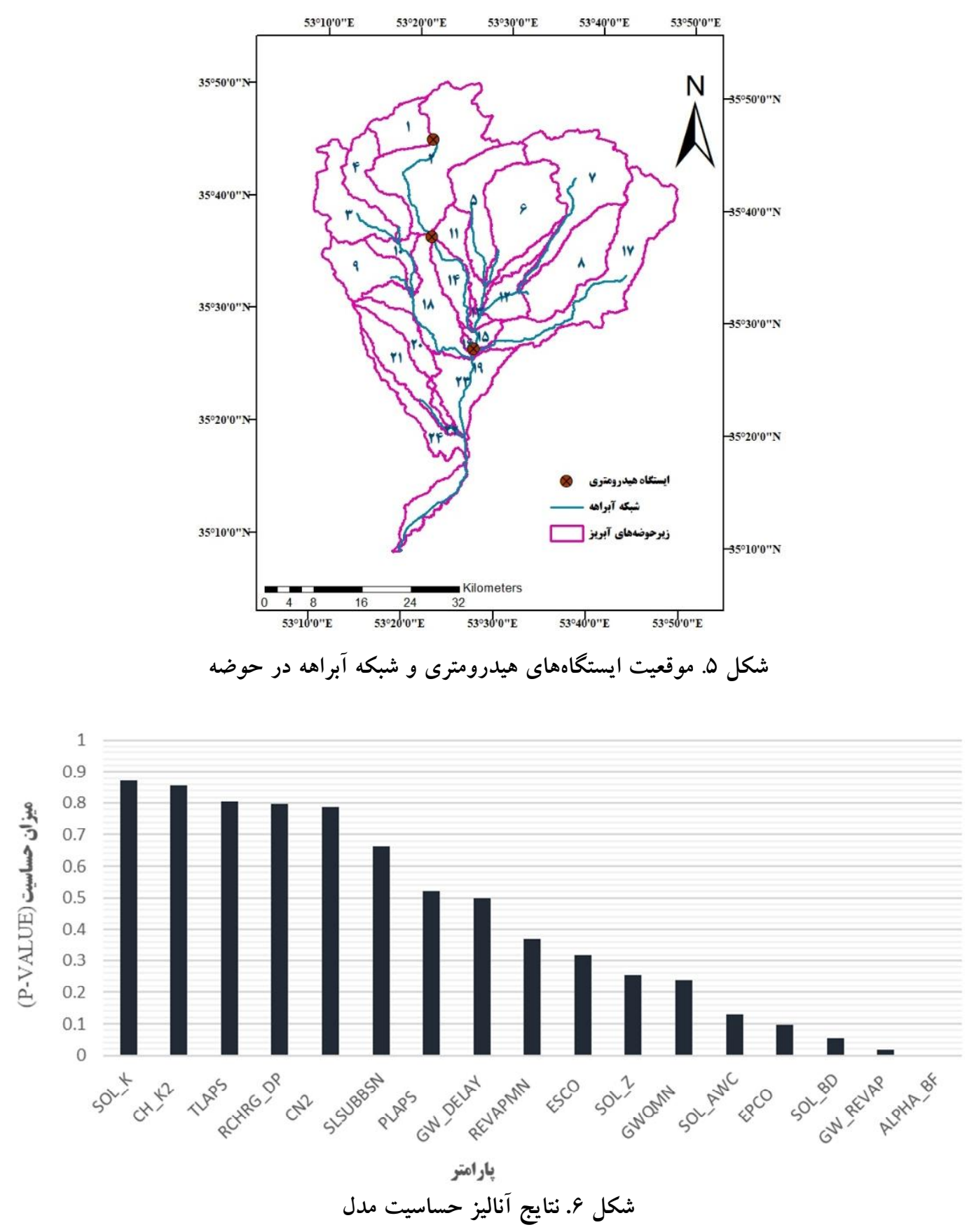

همانطور كه شكل (9) نشان مىدهد، نتايج آنـاليز حساسـيت مــدل

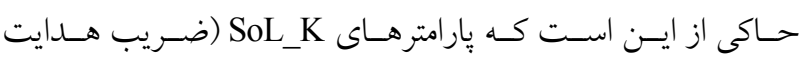

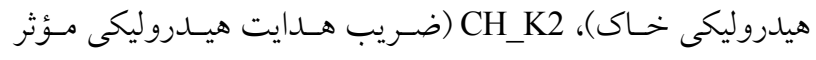

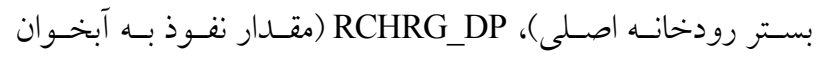

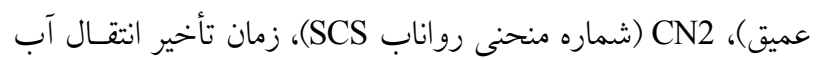

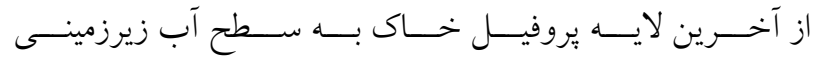
تأثير ويزهاى در نتايج بهدست آمده دارند و جــــ_DELAY)

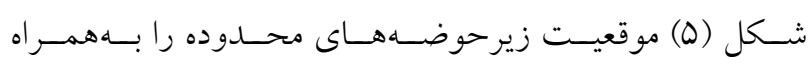
ايستخاههاى هيدرومترى نشان مى دهد. يس از اجرا و واسنجى مــل SWAT خروجسى هـاى مـدل شـامل مؤلفههاى رواناب، جريان زيرسطحى، آب زيرزمينى، تبخيـر -تعـرق

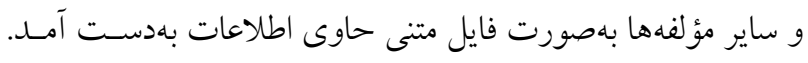


جدول F. نتايج واسنجى و صحتسنجى رواناب ماهانه در ايستخاههاى هيدرومترى

\begin{tabular}{|c|c|c|c|c|c|c|c|c|}
\hline \multicolumn{4}{|c|}{ دوره صحتسنجى } & \multicolumn{4}{|c|}{ دوره واسنجى } & \multirow[t]{2}{*}{ ل } \\
\hline $\mathrm{R}^{2}$ & Ns & r-factor & p-factor & $\mathrm{R}^{2}$ & Ns & r-factor & p-factor & \\
\hline $0 / \Lambda 0$ & $0 / 90$ & $\circ / \Delta Q$ & $1 / \Lambda$ & ०/^९ & $\circ / V Q$ & $\circ / \Delta \wedge$ & $1 / 0$ & شهميرزاد \\
\hline O/NY & $0 / 9$ & $\circ / \uparrow \wedge$ & $\circ / \wedge \Delta$ & ०/AK &.$/ 90$ & $0 / 40$ & $\circ / \Lambda 1$ & درجزين \\
\hline o/Ar & $\circ / \mathrm{V}$ & $\circ \pi \Delta$ & $\circ / N Q$ & $\circ / \wedge \Delta$ & $\circ / V Y$ & ס & $\circ / \mathrm{VI}$ & حاجى آباد \\
\hline
\end{tabular}

تعديل شدهاند، بنابراين اين امر مسىتوانــ در اتــر نامناسـب بـودن

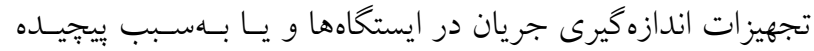
بودن وقايع و دستكارىهاى بشـر در حوضـه باشـد. از طرفى در مسير رودخانـه اصـلى برداشـتهـاى متعـدد آب انجـام شــده و بركشت آب در فواصل مختلف به رودخانه نيز صورت مى گيـرد. در شكل (V) نتايج واسنجى اعتبارسنجى مدل در مقياس ماهانسه و سالانه براى ايستخاههاى هيدرومترى نشان داده شده است.

بيالان آب

يس از واسنجى مدل مىتوان نتايج خروجى مدل بهخصوص مؤلفههاى بـيلان را ارزيـابى كــد. كفتنسى اسـت كـه فراينـد واسنجى انجام شده نسبت به جريـان رودخانـه بـوده اسـت. مقادير مؤلفههاى بيلان آب سـطحى بـراى تمـام سـالهــا در دوره شبيهسازى توسط مدل در سطح حوضه آبريز در شكل ارائه شده است كه نشان مى دهد در هر سـال سـهم هـر (N)

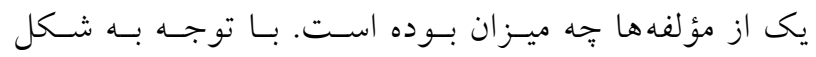
مى توان تغييرات بارش در سالهاى مختلف و تأثير تغييـرات اقليمى را بر ميزان جريان سطحى و زيرزمينى و ديخر عوامل با توجه به سال هاى ترسالى و خشكسالى مشـاهده كـرد. بـا

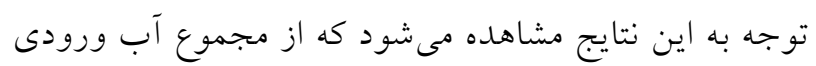

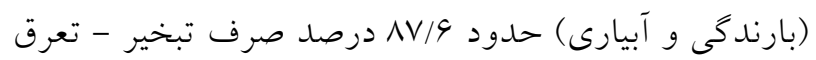

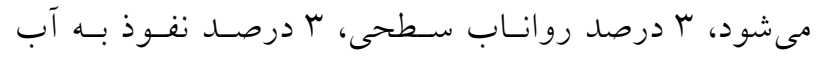
زيرزمينى و مابقى مرتبط بــا تغييـرات و ذخيــره رطوبـت در خاى هستند. در جدول (ه) مقادير جريان خروجى از حوضه از طرق مختلف آورده شده است.
حساسترين يار امترها هستند. مطابق شكل بــا افـزيش مقــدار عـدد منحنى جريان بايه كاهش يافته و رواناب سطحى افزايش مسىيابـ، زيرا با افزايش علد منحنى مقـدار نفــوذ كــاهش يافتــه و باعــث افـزايش روانـاب سطحى مى شـود و بــالعكس. در واقـع مسى تـوان كفت مدل بيشتر تحت تأثير بارامترهـاى آب زيرزمينى (تغذيـهـ بـهـ آبخوان) و يار امترهاى خاى (عمق و نخهاشت آب در خاك) بـوده و مقدار روانـاب در حوضـه بيشـتر بـه ايسن مقـادير وابسـته اسـت بهورى كه تغيير هر يك از آنها در نتايج مدل تأثير گذار بوده است.

اجرا، واسنجى (Calibration) و اعتبارسـنجى (Validation) مدل

با توجه به نتايج بهدست آمده براى معيارهاى سنجش واسـنجى و

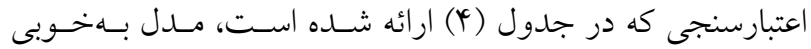
توانسته تغييرات جريـان در رودخانـهـ را شـبيهسـازى كنــ. بــراى سال هاى ابتدايى، شبيهسازى در ايستخاههــا مطلـوبِ بـوده اسـت، نتايج نشان مىدهد كه در بعضى سـالهـا مــل در شـبيهسـازى جريانهاى حداكثر موفق نبوده است و كمبرآورد داشته است. اين امر مىتواند بهدليل افزايش برداشتها از آب سطحى در بالادست باشد. غيرعادى بودن و اختلاف جريان واقعى و شـبيهسـازى در بعضى سالها احتمالاً بهدليل خطاى اندازهيرى در جريان اسـت.

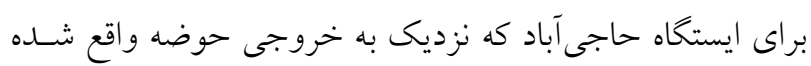

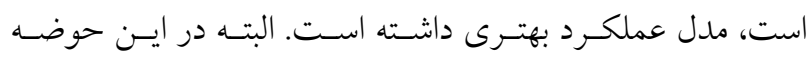
مشكل كم برآورد كردن جريانهاى حداقل در برخى سالهــا نيـز

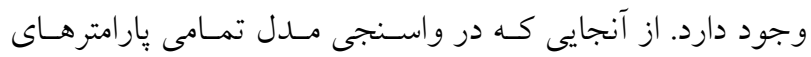
مؤثر در محاسبه جريان بايه تا حد امكان بـراى حـل ايسن مسـئله 

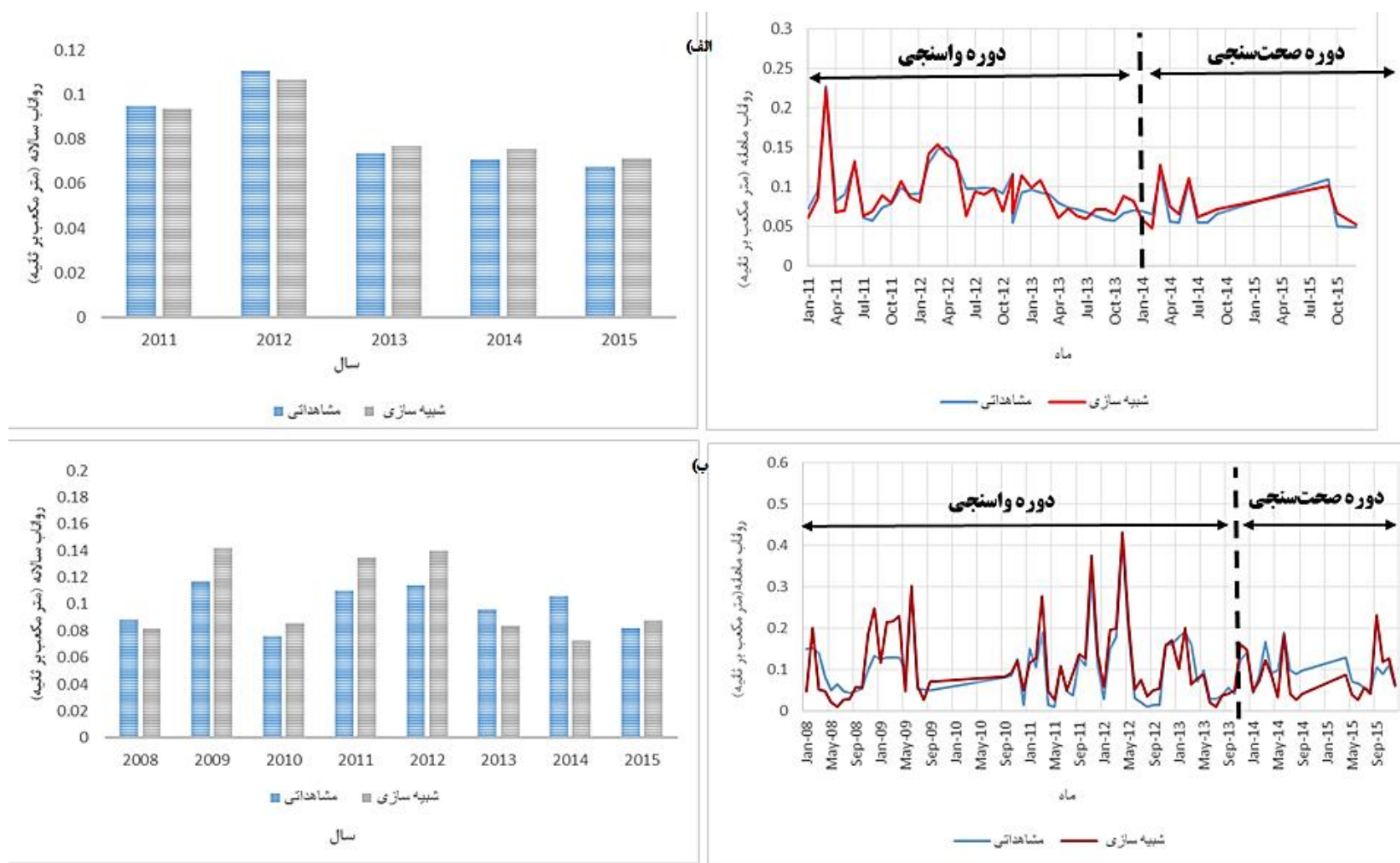

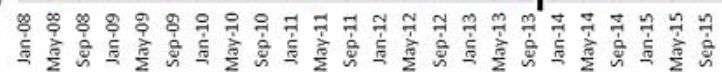
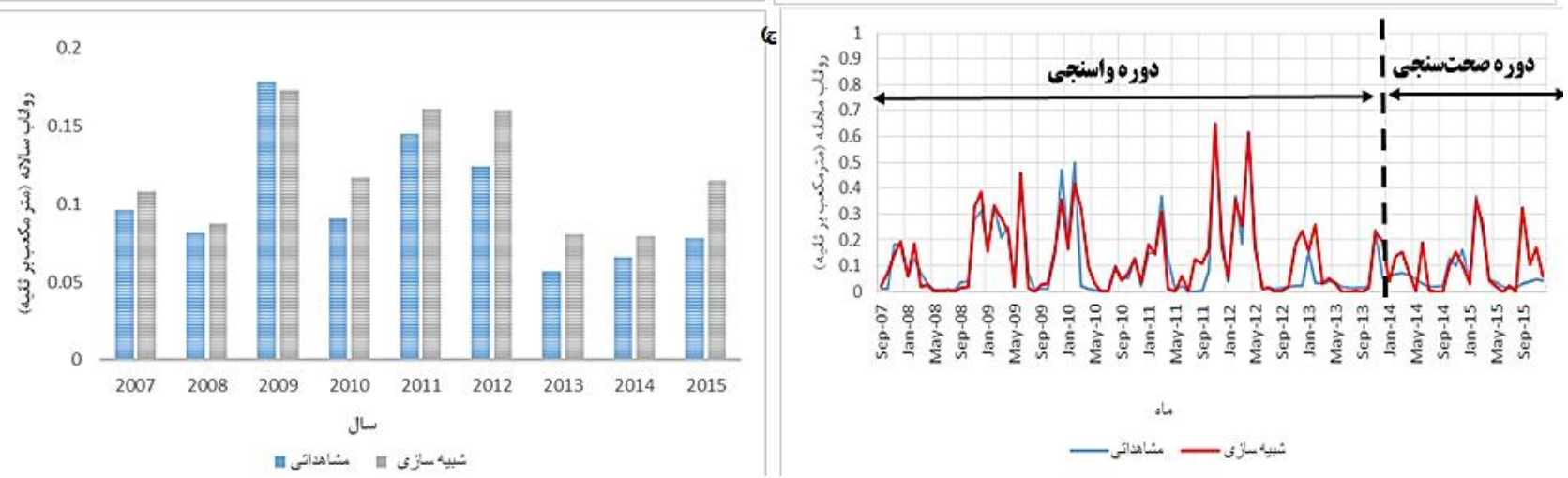

شكل v. نتايج واسنجى - صحتسنجى مدل در مقياس ماهانه و سالانه: الف) ايستخاه شهميرزاد، ب) ايستخاه درجزين وج) ايستخاه حاجى آباد (رنغى در نسخه الكترونيكى)

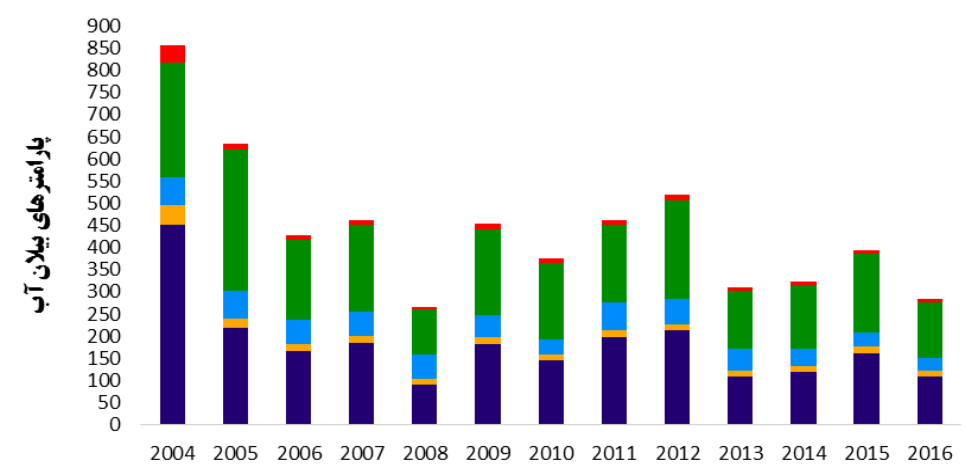
سال

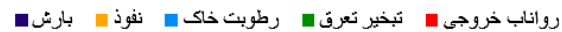

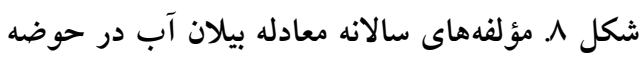




\section{جدول ه. مؤلفههاى خروجى مدل SWAT برحسب ميلى متر}

\begin{tabular}{|c|c|c|c|c|c|}
\hline تبخير - تعرق واقعى & رواناب خروجى از حوضه & نقوذ به آبخو ان & جريان جانبى & رواناب سطحى & 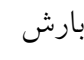 \\
\hline $\mid Q Y / 9$ & $11 / 4$ & IV/r。 & $10 / 10$ & $1 / 00$ & $1 \wedge r / 0$ \\
\hline
\end{tabular}

غالب هيدرولوزيك در منطقه و همجنين فعاليتهـا و دخالـتهـاى انسانى در جرخه هيدرولوزيكى در حوضـه اسـت. بـهـنـوان مثـال عوامل متعددى از جمله برداشتهاى ينهان آب در مسـير رودخانـه بهخصوص در مناطق بالادست و در فواصـل نـامعلوم از رودخانـه، مشخص نبودن مقدار دقيق آب بركشتى به رودخانـه، عـدم وجـود آمار دقيق در مقياس زمانى مناسب از برداشـتهــاى انجـام شــده از منابع آب سـطحى، عـدم وجــود آمـار دقيـق و مــدون از مـديريت كثـاورزى در منطقـهـ و ضـعف در انــازهذيـرى دقيـق جريـان در ايستخاههـاى هيــرومترى از سـاير منـابع ايجـاد عـــم قطعيـت در خروجى مدل هستند. از طرف ديخر برخى از كاسـتى هـاى مـدل از جمله ضعف مدل در شبيهازى ذوب برف و سـهم آن در تشـكيل دبى بايه در مناطق مرتفع نيز مىتوانند منجر به عـــم انطبـاق كامـل جريان شبيهسـازى و انـدازهذيـرى شـده شـود (V). ارزيـابى نتـايج خروجى مدل نشـان داد از مجمـوع آب ورودى بـه حوضـه، NV/9

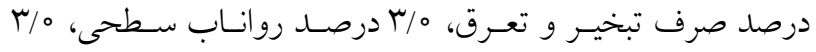
درصد نفوذ عمقى و مابقى مرتبط با تغييرات و ذخيـره رطوبـت در خاك است. در واقع بيشترين سهم يارامترهاى بيلان را تبخير تعـرق دربرمى گيرد و سهم تغذيه آب زيرزمينى از طريق آب سـطحى تنهـ r درصد است كه با توجه به اين مقدار نقوذ به آبخوان بايسـد ميـزان حجم برداشتى از حوضه را كنترل كـرد. در مجمـوع نتـايج تحقيـق حاكى از اين است كه مدل SWAT قابليت شبيهسازى بـيلان آبسى حوضههاى آبخيز با شرايط يبيجيده و ناهمخن را بـا دقـت مناسـب دارا است. البته بهشرط اينكه دادههاى ورودى بـا دقـت مناسـب در مدلسازى استفاده شوند و نيز دقت و توجه كافى در واسنجى مـدل صورت گيرد تا مدل هرجهه بيشـتر معـرف شـرايط واقعى حوضـه باشد. اين مطالعه اطلاعات مفيـدى را در مـورد جريـان رودخانـه و

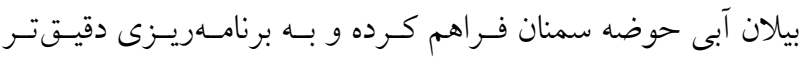

\section{بحث و نتيجه گيرى}

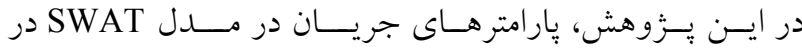

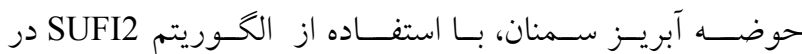
نرمافزار SWAT-CUP واسنجسى و حساسيتسنجى شد. بـراى واسنجى و ارزيابى مدل از دادههاى جريان رودخانه ثبـت شــه در سه ايستخاه هيدرومترى شهميرزاد، درجزين و حاجى آبـاد در سطح حوضه استفاده شد. بـا توجـهـ بـهـ نتـايج حاصـل از آنـاليز حساسيت، پِرامترهـاى SOL_K حساسترين يارامترها بودند. نتايج شاخص نش ساتكليف (NS) و ضـريب تبيسين (R²) بـراى ايستـاه شـهميرزاد واقـع در ارتفاعـات

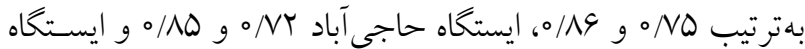
درجزين 190/ه و سم/ه در دوره واسنجى بــرآورد شـــ. ابراهيمسى و

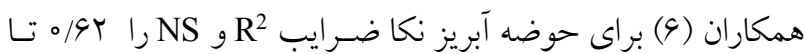

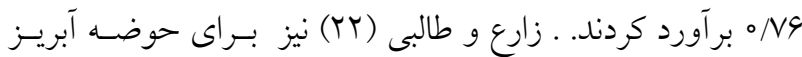
قرهسو مقدار ايسن ضـرايب را وس/ه و 9/ه بــراى دوره واسـنجى و

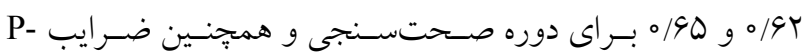
و R-factor factor س/ ابراى دوره صحتسنجى بهدست آوردنل. براى حوضـه آبريـز

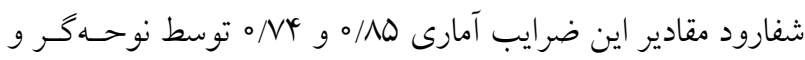
همكاران (9) تخمين زده شد. مقايسه با نتايج مطالعات انجام شـده در حوضههاى مختلف حاكى از عملكـــد رضـايتبخـش مـدل در محدوده است. با وجود مناسب بودن مقادير معيارهاى ارزيابى مــل در حوضه، در برخى از سالها مقدار جريان شبيهسازى شده نسبت به جريان اندازه گيرى شده بيشبرآورد و يا كمبرآورد شده است كـهـ البته روند مشخصى در اين خصوص مشاهده نمسىشـود. لــا ايسن عدم انطباقها ميان جريان شبيهسازى و اندازه گيـرى شــده ناشسى از خطاى سيستماتيك نيست، بلكه مرتبط با ماهيت بيبجيده فراينـدهاى 


$$
\begin{aligned}
& \text { سياسگز ارى } \\
& \text { يروزههاى منابع آب كمك مى كند. از نتايج ايسن يـزَوهش مسىتـوان } \\
& \text { اين تحقيق بخشى از طرح بِزوهشى تصويب شده در وزارت نيرو } \\
& \text { براى بيشبينى اثرات تغيير اقليم و اقدامات مـــيريتى قابـل اجـرا در } \\
& \text { است كه بدين وسيله از اين نهاد قدردانى و سِاسخز ارى مى شعود. } \\
& \text { منطقه كه بهصورت سناريوهايى به مدل ارائه مسىشـود و همجنـين } \\
& \text { استفاده از نتايج آن براى تلفيق با مدلهاى آب زيرزمينسى بـهـمنظـور } \\
& \text { بررسى وضعيت آبخوانها استفاده كرد. }
\end{aligned}
$$

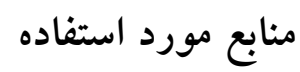

1. Abbaspour, K. C., J. Yang and R. Maximov Siber. 2007. Modelling of hydrology and water quality in the prealpine/alpine thur watershed using SWAT. Journal of Hydrology 333: 413-430.

2. Abbaspour, K. C., M. Vejdani and S. Haghighat. 2007b. SWATCUP calibration and uncertainty programs for SWAT. Procceding of International Congress on Modelling and Simulation (MODSIM'2007), Melbourne, Australia.

3. Anwar, N. S. 2010. Simulated Impact of land use dynamics on Hydrology during a 20-ear-Preiod of deles basin in Ethiopia. TRITA-LWR Master Thesis, Department of Land and Water Resources Engineering Royal Institute of Technology (KTH).

4. Arnold, J. G., R. Srinivasan, R. S. Muttiah and J. R. Williams. 1998. Large area hydrologic modeling and assessment Part 1. Model development. Journal of the American Water Resources Association 34: 73-89.

5. Azari, M., H. R. Moradi, B. Saghafian and M. Faramarzi. 2013. Assessment of hydrological effects of climate change in Gourganroud river basin. Journal of Water and Soil 27(3): 537-547. (In Farsi).

6. Ebrahimi, P., J. Salimi and M. Mohseni. 2018. Calibration and validation of SWAT model in runoff simulation, case study: Neka Watershed. Watershed Engineering and Management 10: 266-279.

7. Fontaine, T. A., T. S. Cruickshank, J. G. Arnold and R. H. Hotchkiss. 2002. Development of a snowfall-snowmelt routine for mountainous terrain for the soil water assessment tool (SWAT). Journal of Hydrology 262: 209-223.

8. Golshan, M., A. Kavian, H. Rohani and A. Asmali. 2013. Calibration of runoff in Haraz watershed with SWAT model. Iranian Journal of Soil and Water Research 46: 293-303. (In Farsi).

9. Himanshu, S. k., A. Pandey and P. Shrestha. 2017. Application of SWAT in an Indian river basin for modeling runoff, sediment and water balance. Environmental Earth Sciences 76(3): 1-18.

10. Hosseini, M. 2010. Effect of land-use changes on water balance and suspended sediment yield of Taleghan Catchment, Iran. Ph.D Thesis, University Putra Malaysia.

11. Hosseini, M., M. Ghafouri, M. R. Tabayabaei, M. Goudarzi and S. A. Hejazi. 2012. Evaluation of flow components with SWAT model in Taleghan Watershed. Journal of Geography and Planning 45: 27-41. (In Farsi).

12. Khalighi, S. Sh. T., T. Z. Shoae, A. Salajegheh, A. Kohandel and Q. Mortezaei. 2009. Precipitation and runoff simulation by semi distributed method in river basins with deficit date, case study: Latyan Basin. Proceedings of the 5th National Seminar on Watershed Management Sciences and Engineering, Gorgan. (In Farsi).

13. Munoz-Villers, L. E. and J. J. McDonnell. 2013. Land use change effects on runoff generation in a humid tropical montane cloud forest region. Hydrology and Earth System Sciences 17: 3543-3560.

14. Murty, P. S., A. Pandey and S. Suryavanshi. 2014. Application of semi-distributed hydrological model for basin level water balance of the Ken basin of Central India. Hydrological Processes 28(13): 4119-4129.

15. Ndomba, P., F. Mtalo and A. Killingtveit. 2008. SWAT Model Application in a Data Scarce Tropica Complex Catchment in Tanzania. Physics and Chemistry of the Earth 33: 632-626.

16. Nohe gar, H., A. Malekian, M. Hosseini, A. Helisaz and E. Taghvaye salami. 2017. Difference between Sufi2 and Glue algorithms in simulation of run off in forest catchment in Shafarood watershed. Caspian Journal of Environmental Sciences 8(4): 389-399. (In Farsi)

17. Portoghes, I., V. Uricoohio and M. Vurro. 2005. A GIS tool for hydrological water balance evaluation on a regional scale in semi-arid environments. Computers \& Geoscience 31: 15-27.

18. Rafiei Emam, A., M. Kappas, S. Akhavan, S. Z. Hosseini and K. C. Abbaspour. 2015. Estimation of groundwater recharge and its relation to; and degration: case study of a semi-arid river basin in Iran. Environmental Earth Sciences 74: 6791-6803.

19. Scheffler, R., C. Neill, A. V. Krusche and H. Elsenbeer. 2011. Soil hydraulic response to land-use change associated with the recent soybean expansion at the Amazon agricultural frontier. Agriculture, Ecosystem and Environment Journal 144: 281-289. 
20. Thampi, S., K. Raneesh and T. V. Surya. 2010. Influence of scale on SWAT model calibration for stream flow in a river basin in the humid tropics. Water Resources Management 24(15): 4567-4578.

21. Yapo, P. O., H. V. Gupta and S. Sorooshian. 1996. Automatic calibration of conceptual rainfall-runoff models: sensitivity to calibration data. Journal of Hydrology 181: 23-48.

22. Zare Garizi, A. and A. Talebi. 2016. Simulation of water budget in Ghareh sou watershed using swat model. Journal of Water Resources Engineering 9: 97-50. (In Farsi) 


\title{
Investigating of Surface and Ground Water Changes in Semnan Watershed using the SWAT Model
}

\author{
Sh. Nasiri ${ }^{1,2 *}$, N. Farrahi ${ }^{1}$ and A. N. Ziaei ${ }^{2}$
}

(Received: August 27-2019; Accepted: December 14-2019)

\begin{abstract}
One of the most important and complex processes in the watersheds is the identification and prediction of surface water changes. The main processes associated with surface water include precipitation, percolation, evapotranspiration and runoff. In this research, the semi-distributed model, SWAT, was used to simulate ground water and surface water in Semnan catchment in a monthly scale. A sensitivity analysis was perfomed to evaluate and demonstrate the influence of the model parameters on the four major components of water budget including surface runoff, lateral flow, groundwater and evapotranspiration. River discharge data from 2004 to 2014 were used for the calibration and those of 2014 to 2016 were applied for the validation. The results of sensitivity analysis showed that the most sensitive parameters were: SoL K(Saturated hydraulic conductivity), CH K2 (Effective hydraulic conductivity in main channel), RCHRG_DP(Deep aquifer percolation fraction and CN2 (Moisture condition II curve number). The simulation accuracy using Nash-Sutcliffe and coefficient of determination for Shahrmirzad, Darjazin, and Haji Abad hydrometric stations was about 0.60 to 0.80 and 0.80 to 0.90 for the calibration and validation period, respectively, showing a good performance in the simulation of river flow. According to the water balance results, about $87.6 \%$ of the total inflow into the watershed was actual evapotranspiration, $3 \%$ was surface run off, $3 \%$ was percolation, and the rest was related to the soil moisture storage.
\end{abstract}

Keywords: Runoff, Percolation, Sufi2 algorithm, Groundwater, Water balance

1. Water Resources Expert, Hydrotech Toos Consulting Engineers Co.Mashhad, Mashhad, Iran.

2. Department of Water Science and Engineering, Ferdowsi University of Mashhad, Mashhad, Iran.

*: Corresponding author, Email: sh.nasiri.fum@gmail.com 